\title{
Growth Factors in Human Disease: The Realities, Pitfalls, and Promise
}

\author{
By C. William Castor and Antonio R. Cabral
}

$\mathbf{T}^{\mathrm{H}}$ HE LITERATURE related to growth factors increases at such a rapid rate that the cynical might postulate factors governing the development of new growth factors. In an effort to put a manageable perimeter around the subject, this review focuses primary attention on well characterized growth factors, known or suspected to exist in man.

While a universally accepted definition of a growth factor does not exist, usage accepts growth factors as relatively small proteins that induce increased cell synthesis of nucleic acids, protein, and increased cellular mass. Conventionally, growth factors are considered to be agents with mitogenic activity. However, in connective tissues where a disproportionately small number of cells participate in the formation of a large extracellular matrix, growth may be manifested not only by increased cell numbers, but also by increases in one or several components of the extracellular matrix. The physiologic import of this distinction is not trivial when one recalls that approximately $75 \%$ of the human body is of mesenchymal origin, and that skeletal tissues, skin, and fascia (excluding muscular components) account for $>33 \%$ of the body mass. ${ }^{1,2}$ Also, it is pertinent to note that one of the first known growth factors, sulfation factor, was measured by its growth promoting activity as judged by the increased sulfated glycosaminoglycan (GAG) content of cartilage extracellular matrix. Sulfation factor was subsequently shown to be several proteins constituting a group of human growth hormone dependent proteins, members of the somatomedin family; knowledge of their mitogenic properties was a later development.

The same principle applies to epithelial tissues; for example, epidermal growth factor (EGF) stimulates not only replication of cells, but formation of extracellular material such as keratin. Similarly, connective tissue cells exposed to EGF respond with both increased cell replication and increased synthesis and secretion of hyaluronic acid, an extracellular matrix component.

Although the notion of growth promotion evokes the impression that growth factors are primarily concerned with anabolic events, it may be wise to visualize growth as a net increment in cells and certain of their extracellular products. Some growth factors also promote events whose primary impact is catabolic; connective tissue activating peptide-III. (CTAP-III), primarily known for its mitogenic and GAG stimulating properties, also stimulates synthesis and secretion of a degradative protease, plasminogen activator. ${ }^{3}$ Similarly, interleukin-1 (Il-1), a potent stimulator of anabolic processes, also promotes synthesis and secretion of collagenase and prostaglandins by many types of sensitive cells. It seems likely that some growth factors evoke both anabolic and catabolic behavior by a single cell. The mechanism(s) for organized integration of these opposing metabolic vectors in intact organisms will be a focus of investigative effort in the future.

Earlier debate aimed at classifying growth factors as hormones or autacoids now seems moot in the face of new data and the recognition of the depth of our ignorance. For instance, it seems likely that the several growth factors released from platelet alpha granules after platelet aggregation exert a potent local effect, thus behaving as autacoid mediators. Yet, there are no data to rule out significant distant (hormonal) biological effects from these substances, at least some of which are found in plasma. In the case of

From the Department of Internal Medicine, Rackham Arthritis Research Unit, The University of Michigan Medical School, Ann Arbor.

C. William Castor, MD: Professor of Internal Medicine, The University of Michigan Medical School; Antonio R. Cabral, MD: Postdoctoral Fellow in Rheumatology, The University of Michigan Medical School.

Supported by US Public Health Service Grant No. AM10728.

Address reprint requests to $C$. William Castor, $M D$, Rackham Arthritis Research Unit, Department of Internal Medicine. University of Michigan Medical School, Ann Arbor, MI 48109.

(C) 1985 by Grune \& Stratton, Inc.

0049-0172/85/1501-0002\$5.00/0 
the insulin-like growth factors (IGF-I and IGFII) both the site(s) of origin and action are uncertain!

\section{METHODS FOR DETECTING AND MEASURING GROWTH FACTORS}

Bioassay is the initial technique for detecting and measuring a growth factor; it requires discovery of a factor dependent event in whole animals, tissue fragments, or cultures. Nerve growth factor (NGF), for instance, was shown to enhance the growth of sympathetic ganglia in vitro and to elicit neurite outgrowth from embryonic sympathetic and sensory ganglia explanted in vitro. ${ }^{4}$ In a more exotic vein, fractions containing EGF injected into newborn mice caused precocious opening of the eyelids and premature eruption of the incisors, thus forming the basis of a bioassay. ${ }^{5}$ Observations of this nature provide investigators with the initial assays that permit protein fractionation studies aimed at isolating the responsible agent(s).

A different, and sometimes more quantitative, dimension was added to the study of growth factors when investigators examined selected specific effects of these agents, commonly using tactics to measure cell replication or increased DNA synthesis. Alternatively, one may measure increased synthesis of extracellular matrix components (eg, glycosaminoglycans, proteoglycans, collagen, keratin) using appropriate isotopic or chemical methodology. Weaknesses of this approach derive from the fact that crude mixtures may contain several components able to stimulate a responsive cell system, or may include inhibitors able to modify the cellular responsiveness in a misleading fashion in the opposite direction. Nonetheless, the bioassay is necessarily the guide for investigators attempting to isolate highly purified principles from crude mixtures by protein fractionation techniques.

Isolation (guided by bioassay) of a growth factor in a homogeneous form opens many new doors. The purified material may be used to develop antisera useful for detection of the factor by immunodiffusion, its measurement by radial immunodiffusion (RID), radioimmunoassay (RIA), or enzyme linked immunoassay (ELISA). Alternatively, the availability of the purified growth factor may allow preparation of a radiolabeled conjugate so that it may be detected and measured in membrane receptor assays. Immunologic methods, however, may fail to distinguish between active and inactive forms of a particular molecule, in addition to possible problems related to cross reactivity; radioreceptor assays may also on occasion give rise to nonspecific results.

\section{WELL DEFINED HUMAN GROWTH FACTORS}

A partial list of well defined growth factors that may have biological importance in humans is shown in Table 1.

Table 1. Growth Factors that Stimulate Connective Tissue Cell Replication and Extracellular Matrix Synthesis

\begin{tabular}{|c|c|c|c|c|}
\hline & Source & $\begin{array}{l}\text { Purification } \\
\text { Status }\end{array}$ & $\begin{array}{l}\text { Molecular Weight } \\
\text { (Daltons) }\end{array}$ & Possible Clincal Significance \\
\hline EGF & Platelets (?) & Sequenced & 6.045 & Wound healing. neurofibromatosis \\
\hline CTAP-III & Platelets & Sequenced & 9.278 & $\begin{array}{l}\text { Inflammation, wound healing, athero- } \\
\text { sclerosis, neoplasia }\end{array}$ \\
\hline PDGF & Platelets & $\begin{array}{l}\text { Partially } \\
\text { sequenced }\end{array}$ & 31,000 & $\begin{array}{l}\text { Inflammation, would healing, athero- } \\
\text { sclerosis, neoplasia }\end{array}$ \\
\hline IGF-1/SM-C & Plasma & Sequenced & 7,649 & Leprechaunism, mediates hGH action \\
\hline$|\mathrm{GF}-1|$ & Plasma & Sequenced & 7.471 & Mediates hGH action \\
\hline $\mid L-1$ & $\begin{array}{l}\text { Human } \\
\text { monocytes }\end{array}$ & $\begin{array}{l}\text { Highly purified, } \\
\text { nonhomogeneous }\end{array}$ & $11,000-15,000$ & $\begin{array}{l}\text { Mediates immune responses, connec- } \\
\text { tive tissue growth and wound heal- } \\
\text { ing. An endogenous pyrogen }\end{array}$ \\
\hline NGF & $\begin{array}{l}\text { Uncertain } \\
\text { in humans }\end{array}$ & $\begin{array}{l}\text { Active subunit } \\
\text { sequenced }\end{array}$ & 13,259 & $\begin{array}{l}\text { Maintenance of sympathetic nervous } \\
\text { system, neural neoplasms, Alz- } \\
\text { heimer disease }\end{array}$ \\
\hline CTAP_PMN & Human PMN & $\begin{array}{l}\text { Highly purified, } \\
\text { nonhomogeneous }\end{array}$ & $12,000-16,000$ & Wound healing, inflammation \\
\hline CTAP-U & Human urine & $\begin{array}{l}\text { Highly purified, } \\
\text { nonhomogeneous }\end{array}$ & $16,000-30,000$ & Unclear \\
\hline
\end{tabular}




\section{EGF-Urogastrone}

EGF was first described in the mouse submaxillary gland and later isolated from human urine (as urogastrone) ${ }^{6}$ Computer based studies indicate that the precursor of mouse EGF (mEGF) has substantial similarity to bovine factor $\mathrm{X}$, data supporting the concept that EGF arose early in vertebrate species. ${ }^{7}$ New evidence localizing an EGF-like material in the human platelet alpha granule argues that it may be synthesized by megakaryocytes in humans. ${ }^{8}$ Aspects of the discovery, isolation, and mechanism of action of EGF have been summarized."10 EGF from mouse submaxillary gland and human urine is a heat stable acidic polypeptide chain; it has been sequenced and shown to have 53 amino acid residues and three intramolecular disulfide bonds. Synthesized and stored in the submandibular gland, $\mathrm{mEGF}$ is found in granular form in convoluted tubules.

In vivo, EGF stimulates cell proliferation, keratinization, premature eruption of incisors and inhibits gastric acid secretion. Merino sheep, infused with EGF, showed temporary cessation of follicular activity, and wool protein became abnormal. " Palatogenesis during embryonic development may be controlled in part by EGF; the presumed mechanism involves increased concentration of environmental hyaluronic acid, thought to be critical for palatal shelf elevation and/or fusion of medial epithelium. ${ }^{12}$

In vitro actions of EGF-urogastrone include stimulation of cell proliferation in many types of epithelial and fibroblastic cells. EGF induces increased synthesis of DNA, RNA, cyclic nucleotides, and enhanced transport of nutritional precursors. In appropriate cell types, EGF stimulates synthesis and secretion of specialized proteins (as prolactin or collagen) and complex carbohydrates (as hyaluronic acid). EGF induced stimulation of prolactin synthesis in rat pituitary celis apparently depends on accelerated transcription of the prolactin gene. ${ }^{13}$ Although mEGF caused selective dose dependent synthesis of collagen fibers by rat liver epithelial cells, ${ }^{14}$ it had little effect on collagen formation in cultures of rat liver fibroblasts ${ }^{15}$ and reduced collagen synthesis in mouse osteoblastic cultures. ${ }^{16}$ Such data emphasize and ambiguities in growth factor bioassays that may result from the choice of species or tissue type used to serve as a target system.

Binding of EGF to specific fibroblast receptors is irreversible; it is followed by phosphorylation of the receptors, internalization, and proteolytic processing in lysosomes. Remodeled receptor fragments may serve as intracellular signals for the multiple specific actions attributed to EGF. ${ }^{17}$ The gene coding for the human EGF receptor is believed to reside on chromosome No. $7{ }^{18}$ Peptides derived from the receptor protein show a high degree of homology with the deduced sequence of the v-erb-B transforming protein of the avian erythroblastosis virus. ${ }^{19}$ Retrovirus transformed rat fibroblasts have been shown to synthesize and secrete a transforming growth factor type I (rTGF-I, also, rTGF $\alpha$ ) that shows substantial sequence homology with the mEGFurogastrone family and shares the same biological activities. ${ }^{20}$ TGF- $\beta$, said to be present in normal cells and stored in platelets, is unrelated to EGF structurally or functionally, but regulates the number of receptors for EGF in certain cell types. ${ }^{21}$ Monoclonal antibodies against the EGF receptor protein induce some of the effects of EGF itself, including stimulation of thymidine incorporation into DNA. This observation supports the concept that information in the EGFmembrane receptor system resides primarily in the membrane receptor itself. ${ }^{22}$

Recently, a chemically synthesized gene for $\mathrm{hEGF}$ was expressed in yeast; the resultant biosynthetic hEGF was shown to compete with ${ }^{125} \mathrm{I}-\mathrm{mEGF}$ in a receptor binding assay using human dermal fibroblast plasma membranes ${ }^{23}$ and was reported to elicit precocious eyelid opening, incisor eruption, and inhibition of gastric secretion. Although this study yielded small quantities of $h E G F$, the methodology has potential for providing large enough amounts of this protein to permit full exploration of its many possible biological and medical applications. For instance, topically applied EGF has been reported to promote healing of corneal ulcers. ${ }^{24}$

Physiologic control of EGF as well as the pathophysiologic roles of this peptide are yet dimly lit arenas. In the mouse, EGF is known to be regulated by androgens; recent evidence indicates that thyroid hormones and adrenocortical hormones also regulate EGF in this species. ${ }^{25}$ In senescent mice, the submandibular glands appar- 
ently contain decreased amounts of EGF. ${ }^{26}$ Binding sites for EGF in skin fibroblasts from patients with neurofibromatosis were greatly diminished compared with age and passage matched normal strains. ${ }^{27}$

\section{Platelet Factors}

It is clear that human platelets contain both cationic and anionic growth factors; one laboratory reported three different forms. ${ }^{28}$ Current interest centers on four classes of growth promoting proteins, cationic proteins such as connective tissue activating peptide-III (CTAP-III) and the several molecular forms of platelet derived growth factors (PDGF), and anionic platelet derived growth factors including CTAP-P ${ }_{2}$ and possibly EGF.

\section{Connective Tissue Activating Peptide-III}

This thrombin releasable growth promoting factor in human platelets has been isolated and studied in detail. ${ }^{29,30}$ CTAP-III, isolated from both fresh and outdated human platelets, is a 9,278-dalton single chain protein with an average isoelectric point of $8.5 .^{31}$ Recent data show isoelectric point related microheterogeneity that modifies growth factor activity. Amino acid sequence and immunologic studies demonstrate that CTAP-III differs from $\beta$-thromboglobulin ( $\beta$-TG) by an additional amino terminal tetrapeptide. ${ }^{31,32}$ Proteolytic removal of the amino terminal tetrapeptide degrades CTAP-III to $\beta$ TG and obliterates growth factor activity. Growth factor activity, as measured by enhanced DNA or GAG synthesis in human fibroblast cultures, also depends on the intact status of one or both of the two intrachain disulfide bonds. Specific antisera directed against CTAP-III resulted in immunoprecipitation and loss of mitogenic activity from solution.

Depending on the characteristics of the preparation, nanogram to microgram quantities of CTAP-III stimulate synthesis of DNA, hyaluronic acid, sulfated GAG chains, proteoglycan monomer, and proteoglycan core protein in human fibroblast cultures. CTAP-III also stimulates glucose transport, formation of prostaglan$\operatorname{din} E_{2}$, hyaluronic acid synthetase activity, and the synthesis and secretion of plasminogen activator.

Elevated plasma CTAP-III levels have been demonstrated by radioimmunoassay in rheumatoid arthritis, systemic lupus, and other forms of vasculitis and appeared to parallel clinical disease activity, ${ }^{33,34}$ suggesting a possible pathogenetic role for CTAP-III. CTAP-III antigen and biological activity were found in platelets of growth hormone deficient children, indicating that CTAP-III is not human growth hormone dependent. ${ }^{35}$

\section{Connective Tissue Activating Peptide- $P_{2}$ (CTAP-P ${ }_{2}$ )}

CTAP- $P_{2}$ is an anionic platelet factor ${ }^{36,37}$ and like CTAP-III, CTAP-P $\mathrm{P}_{2}$ is a potent mitogen for synovial, cartilage, lung, and skin fibroblasts and stimulates hyaluronate and sulfated GAG formation in these cell cultures. Unlike CT $\Lambda$ P-III and PDGF, CTAP- $P_{2}$ has an acidic pI (approximately 4.5) with an apparent molecular weight of 19,000 daltons. It has been separated from albumin by immunoaffinity chromatography, and shown to be immunologically different from CTAP-III. CTAP- $P_{2}$ does not compete with EGF in radioreceptor assays (M.D. Hollenberg and D.N. Orth, personal communications, 1984).

\section{Platelet Derived Growth Factor(s) (PDGF)}

Preparations have been interpreted to suggest that PDGF is a molecule with two disulfide linked chains, each with a molecular weight of 14,000 to 16,000 daltons. ${ }^{38}$ PDGF is generally believed to exist in two forms: PDGF-I and PDGF-II whose molecular weights are 31,000 and 28,000 daltons, respectively. ${ }^{39}$ Differences in glycosylation lead some to postulate four molecular forms of PDGF ${ }^{40}$ Preliminary sequence studies of PDGF show no resemblance to CTAPIII. ${ }^{41}$ Of considerable interest are two reports suggesting that a transforming protein from simian sarcoma virus and one PDGF peptide chain are so closely related as to indicate that they are derived from the same or closely related genes. ${ }^{42.43}$

Partially purified PDGF modified lipid metabolism by enhancing cholesterol synthesis and increasing the number of LDL receptors in monkey aortic muscle cells. ${ }^{44}$ It now appears that PDGF is capable of stimulating cell division without the need for progression factors in plasma. ${ }^{45}$ PDGF is chemotactic for fibroblasts and 
vascular smooth muscle cells; ${ }^{46}$ another study showed that three platelet alpha granule proteins, platelet factor $4, \beta-T G$, and PDGF each exhibited chemotactic activity for human skin fibroblasts. ${ }^{47}$ Studies of PDGF interactions with fibroblast receptors suggest that PDGF and EGF are not processed via a common pathway. ${ }^{48}$

\section{Epidermal Growth Factor}

EGF must be considered as a possible platelet derived anionic growth factor on the basis of radioimmunoassay and radioreceptor assay data; it appears to be located in the platelet alpha granules and is released during blood coagulation. ${ }^{8}$ In addition to the human platelet derived growth factors, recent reports suggest that human platelets contain an endothelial cell growth factor ${ }^{49}$ and a transforming growth factor (TGF). ${ }^{\text {so }}$ The relationship of platelet EGF to platelet TGF is unclear. Further purification and characterization of these materials will determine whether they are distinct from the better defined platelet derived factors. Thus, it appears that platelets may carry two anionic (EGF and CTAP-P ${ }_{2}$ ) and two cationic (CTAP-III and PDGF) thrombin extrudable factors that are immunologically and structurally distinct. It is not known whether they are derived from a common larger protein or whether they are synthesized as completely separate entities.

\section{Insulin-Like Growth Factors (IGA, I, II) and Somatomedins}

Radioimmunoassay methods that specifically recognized insulin demonstrated that only $7 \%$ of the insulin-like activity of serum was insulin (and consequently suppressible by antiinsulin serum); the remainder was originally designated as nonsuppressible insulin-like activity (NSILA). The NSILA material(s) are themselves growth hormone dependent, and in turn have growth promoting activity in chick embryo fibroblast cultures and in several other systems. NSILA has now been resolved into two entities: insulin-like growth factors I and II (IGF-I, IGF-II) whose covalent structures are known. ${ }^{51}$ IGF-I is a single chain containing 70 residues ( 7,649 daltons) with three disulfide bonds; it exhibits marked homology with proinsulin. ${ }^{51,52}$ IGF-II is a 7,471 dalton protein with three intrachain disulfide bonds, and it shows substantial homology with both IGF-I and proinsulin.

Both IGF-I and IGF-II stimulate DNA synthesis in chick embryonic tissue and ${ }^{35} \mathrm{SO}_{4}$ uptake in rat costal cartilage, ${ }^{53}$ both IGF species also promote mitosis in rabbit lens epithelial cells. ${ }^{54}$ In skeletal muscle, fat, and heart cells, IGF stimulated 2-deoxyglucose (2-dG) uptake, presumably not acting through the insulin receptor. Although IGF was 50 to 100 times more potent than insulin with respect to growth parameters, it was only $1 / 60$ as potent as insulin in stimulating 2-dG uptake by fat cells. ${ }^{55}$

Radioimmunoassay and radioreceptor assays suggested that IGF-I was related to somatome$\operatorname{din} \mathrm{C}$ (SM-C); ${ }^{56}$ recent amino acid sequence analysis of purified SM-C now confirms the identity of SM-C and IGF-I. ${ }^{57}$ Skin fibroblasts were shown by radioimmunoassay to secrete material resembling SM-C; secretion was blocked by cycloheximide and stimulated by hGH (human growth hormone), platelet derived growth factors and fibroblast growth factor (FGF), but not by EGF, thyroxine, or cortisol. ${ }^{58}$ Parenteral injection of ovine growth hormone into hypophysectomized rats resulted in increased tissue extractable IGF-1/SM-C from kidney, heart, liver, lung, and testes; these data support the concept of multiple sites of synthesis coupled with a local site of action. ${ }^{59}$

Radioimmunoassay of IGF-I and IGF-II show IGF-I levels to be elevated in acromegaly and depressed in hGH deficiency. Enhanced secretion of IGF-II with acromegaly is not seen; however, the values are low in hGH deficiency, supporting the belief that both factors are growth hormone dependent. Extra pancreatic tumors associated with hypoglycemia were not associated with increased levels of IGF-I and IGFII. $^{60}$ Leprechaunism, a syndrome characterized by growth retardation, poor muscle development, and absence of fat, may result from deficiency of insulin-like growth factor activity. Some patients with this syndrome were reported deficient in cellular receptors for IGF-I. ${ }^{61}$ The demonstration that synthetic IGF-1/SM-C has biological and immunologic properties identical to the natural product should facilitate the testing of these materials in relevant clinical contexts. ${ }^{62}$

Growth hormone affects cartilage by inducing the formation of secondary substances, soma- 
tomedins (formerly, sulfation factors), which in turn interact with chondrocytes to modify their metabolism. Somatomedins in serum stimulate ${ }^{35} \mathrm{SO}_{4}$ uptake by cartilage from hypophysectomized rats; serum from hypophysectomized rats is less stimulatory than that from normal rats, and administration of growth hormone restored stimulatory activity to the serum of hypophysectomized animals. ${ }^{63}$ Bioassay of somatomedins in human serum disclosed high activity levels in acromegaly; lower levels were found after hypophysectomy and in patients with pituitary dwarfism. hGF injected into hypophysectomized patients or pituitary dwarfs restores human somatomedin levels to the normal range.

At least three somatomedins (A, B, and C) were thought to be present in human plasma; somatomedin A (SM-A) isolated from human plasma has a molecular weight of approximately 7,000 with asparagine at its $\mathrm{N}$-terminus. SM-A stimulates incorporation of ${ }^{35} \mathrm{SO}_{4}$ into $\mathrm{GAG}$ in chick cartilage and DNA synthesis in both chick embryo and human fibroblasts. ${ }^{64}$ Somatomedin B (SM-B) stimulated DNA synthesis in human glial cells and human embryonic lung fibroblasts. ${ }^{65}$ Purification of SM-C from human plasma led to proof that it is identical to IGF-I. Although IGF-I and IGF-II bind to multiplication stimulation activity (MSA) receptors, it may not mean that IGF and MSA are identical; the data may suggest multiple types of receptors for IGF materials. ${ }^{6}$ One review characterized MSA as a rat plasma somatomedin that shares properties with IGF-I, IGF-II, and insulin. ${ }^{67}$

\section{Interleukin 1}

IL-1, the first well defined human monokine, was originally known as lymphocyte activating factor (LAF). It is a potent mitogen for mouse thymocytes and may be an important mediator of inflammation in humans, possibly also acting as an endogenous pyrogen. ${ }^{68,69} \mathrm{II}-1$ is secreted by activated macrophages of human and mouse and by large granular human lymphocytes. ${ }^{70}$ Synthesis of IL-1 may also be triggered by a cell contact dependent process involving activated lymphocytes, and promoted by endotoxins and phagocytosis. IL-1 stimulates helper $T$ cell release of II - 2 , a T cell growth factor. II - I not only has a role in promoting $T$ cell proliferation, but it modifies in vitro immune responses and induces incremental $\mathrm{PGE}_{2}$ and collagenase synthesis and secretion by human synovial cells. ${ }^{71-73}$ Both the murine and human form of IL-1 have been purified to near homogeneity; ${ }^{68,74}$ human IL-1 is heat labile and stable to acid and thiols, and has a molecular weight of 11,000 to 15,000 daltons with an isoelectric point near 7.1.

In addition to the many immunologically oriented activities of $I L-1$, recent studies indicate that this peptide stimulates DNA synthesis in normal human connective tissue cells and promotes formation of major extracellular matrix components, including collagen and glycosaminoglycans. Its high specific activity makes this molecule a candidate for major roles in the inflammatory process.

\section{Connective Tissue Activating Peptide-Urine $(C T A P-U)$}

CTAP-U is a 16 to 30 kilodalton peptide isolated from human urine ${ }^{75}$ that stimulates DNA, hyaluronate, and sulfated GAG formation in skin, synovial, and cartilage fibroblast cultures. Proteolytic digestion destroys its growth factor activity, but biological activity is unaffected by thiol, acid, or heat treatment. Both ion exchange chromatography and preparative isoelectric focusing define two major areas of activity in the ranges of $\mathrm{pH} 2$ to 3 and $\mathrm{pH} 4$ to 5 . Whether this represents two or more different growth factors or microheterogeneity of one agonist is unclear. CTAP-U does not compete in radioreceptor assays with insulin, basic somatomedin, or EGF and is immunologically distinct from CTAP-III, CTAP-P $\mathrm{P}_{2}, \mathrm{IgG}$, and its $\mathrm{Fc}$ and Fab fragments. Little is known about the origin of this peptide(s). It could represent urinary tract associated autacoid(s) or metabolite(s) of growth or nongrowth factor protein(s).

\section{CTAP-PMN}

A human granulocyte derived factor that stimulates DNA and GAG synthesis by human fibroblasts, CTAP-PMN is relatively heat stable, sensitive to thiols, and has a molecular weight between 12,700 and 15,700 daltons. This factor might play a role in chronic proliferative synovitis or in other settings where exudative inflam- 
mation is accompanied by connective tissue growth. ${ }^{76}$

\section{Nerve Growth Factor (NGF)}

Although present in many tissues, NGF is found in high concentrations in some snake venoms and in the male mouse submaxillary gland." It elicits overgrowth of sympathetic chain ganglia in vivo and promotes halo-like outgrowth of nerve fibers from embryonic sympathetic ganglia cultured in vitro. NGF may be important in regulation of neural cell growth and differentiation and may contribute to the survival of peripheral sympathetic and spinal sensory neurons.

NGF isolated from the mouse submaxillary gland is a hexameric 140,000 dalton protein complex composed of $\alpha, \beta$, and $\gamma$ subunits. The $\alpha$ subunit subserves a regulatory function, the $\gamma$ subunit is an arginine esteropeptidase, and the biological activity resides in the $\beta$ subunit. ${ }^{78}$ The $\beta$ subunit of NGF ( $\beta$ NGF) has been sequenced; the primary peptide has a molecular weight of 13,259 daltons and associates in two subunits with a molecular weight of 26,518 daltons. $\beta$ NGF has three disulfide bonds, and the many acidic residues present in the amide form may account for its basic nature. The biological activity of $\beta \mathrm{NGF}$ is inhibited in the hexameric complex; this in turn protects the active component from proteolysis.

Administration of antibodies to NGF to animals causes total destruction of the sympathetic nervous system. NGF may be viewed as a hormone capable of positive pleiotropic stimulation of developing nerve tissue, and may be required in small amounts to maintain a mature sympathetic nervous system. NGF activity immunologically identical to that of submaxillary glands has been found in blood and other peripheral organs. Structural similarities between NGF and proinsulin lead to the suggestion that NGF is related in an evolutionary sense to a primitive form of proinsulin. $^{79}$

There are few unambiguous data confirming the presence of NGF in human tissues. A recent review emphasizes the possible role of nerve growth factor in human neoplasms including sarcoma, neuroblastoma, and gliomas. ${ }^{80}$ Older data suggested that NGF was secreted by a human glioblastoma cell strain. ${ }^{81}$ Further, human melanoma cells in culture were shown by indirect immunofluorescence to possess surface NGF; NGF receptors were thought to be present on the basis of both immunofluorescence and ${ }^{125}$ I-NGF binding. ${ }^{82} \mathrm{~A}$ highly purified receptor for NGF has also been prepared from membranes of a human melanoma cell line by affinity chromatography. ${ }^{83}$

The similarity of physiologic deficits in Alzheimer disease and some functions subserved by NGF led to speculation that this malady may be caused either by a deficiency of NGF or decreased responsiveness of cholinergic neurons to $\mathrm{NGF} .^{84}$ Other lines of evidence indicate that NGF is chemotactic for human leukocytes in vitro at concentrations similar to those that stimulate neurite outgrowth, ${ }^{85}$ suggesting that this peptide may normally modulate nonneural cell function, possibly playing a role in wound repair.

\section{GROWTH FACTORS AND NEOPLASIA}

The fundamental observation that tumor cells conserve the transformed phenotype and that neoplastic transformation may be the result of genetic alteration has important consequences, among others, the ability of malignant cells to produce growth factors capable of lowering or replacing their serum requirements during propagation in vitro. ${ }^{86}$

The concept of neoplastic transformation is being expanded by study of retroviruses, whose presence is thought to be required to initiate and maintain viral transformation. ${ }^{87}$ The viral transforming agents, termed oncogenes, are recognized in vertebrate cellular genes (c-onc) ${ }^{88}$ and can be actively transcribed. ${ }^{89}$ It is believed that they were integrated into the viral genome during vertebrate infection, ${ }^{90}$ and because these protooncogenes are closely conserved during evolution, it is supposed that their normal function is related to the regulation of cell replication and/ or differentiation. ${ }^{90}$

One of the acute transforming retroviruses of primate origin is the simian sarcoma virus (SSV). ${ }^{91}$ Its genome arose by recombination of simian associated virus with a segment derived from a woolly monkey cellular gene ( $v-s i s) .{ }^{92}$ The entire genomic nucleotide sequence has been 
reported, ${ }^{93}$ the transforming gene product has been identified $\left(\mathrm{p} 28^{\mathrm{sis}}\right),{ }^{91}$ and the human homologue (c-sis) has been localized in chromosome $22,{ }^{94}$ with $93 \%$ nucleotide sequence homology between c-sis and v-sis. ${ }^{95,94}$

Recently, two different laboratories ${ }^{42,43}$ independently concluded that a segment of the predicted amino acid sequence of $\mathrm{p} 28^{\text {sis }}$ has identical structural homology $(87.1 \%)$ with the known amino terminal amino acid sequence of one of the PDGF chains. ${ }^{42,95}$ Subsequently, it was found that lysates of SSV transformed NIH-3T3 cells contain a growth factor that is identical to PDGF in immunoassay and has a mitogenic activity that is absent in nontransformed control cell lysates. This PDGF-like material has a different molecular weight $(20,000$ daltons $)$ in SDS gels after immunoprecipitation with anti-PDGF antiserum; it is supposed that this represents the degraded product of $\mathrm{p} 28^{\text {sis }}{ }^{97}$ These findings raise interesting questions in view of the fact that $\mathrm{p} 20^{\text {sis }}$ is not secreted ${ }^{97}$ and that PDGF by itself does not induce neoplastic transformation. ${ }^{98}$

$A$ recent report ${ }^{19}$ indicated that the predicted $v$-erb-B transforming protein amino acid sequence closely resembles the partially known sequence of the transmembrane and the cytoplasmic kinase domains of EGF receptor. Interestingly, it appears that the avian erythroblastosis virus carries in its genome the encoding sequences of an abnormal EGF receptor that lacks its binding region, perhaps leading to constant generation of a signal similar to that produced by EGF, with subsequent rapid and autonomous cell proliferation. ${ }^{19,99}$ There is evidence that other growth factor receptors besides EGF, including PDGF, insulin, and IGF-I have tyrosine kinase activity, along with the recognition that other encoded oncogene products (such as pp $60^{\text {v-sre }}$, P90 gag-yes,$P 85^{\text {gag-fes }}$ ) have this kind of enzymatic activity. ${ }^{100}$ Some are structurally related to the bovine cAMP dependent protein kinase catalytic chain, ${ }^{101}$ providing further support for the notion that transformation might occur as a result of alteration(s) at multiple points along the mitogenic pathway. It is possible, then, that more than one signal is needed to induce oncogenic cell behavior. Perhaps several oncogenes act in concert and the action of one controls another, enhancing, inducing, or alter- ing the expression of a normal or defective growth factor cascade and/or its receptors. ${ }^{102}$ This would be expected not only to modulate cell replication, but also the synthesis and secretion of a myriad of proteins that in turn modulate gene expression.

\section{GROWTH FACTORS AND THE INFLAMMATORY PROCESS}

Fifteen years ago, studies in cell to cell communication were initiated by adding leukocytes or thrombocytes to synovial membrane derived connective tissue cells in monolayer cultures to simulate the mixed cell population found in rheumatoid synovium. Soluble factors from both intact and lysed lymphocytes, PMN leukocytes, and platelets were shown to activatc synovial fibroblasts by greatly stimulating glucose consumption and connective tissue matrix formation, particularly hyaluronic acid; further, the platelets stimulated cell replication. ${ }^{103,104}$ Subsequently, many more protein mediators have been identified and reviewed. ${ }^{105}$

Circumstantial evidence suggests that many of the known growth factors are reasonable candidates to play roles in acute and chronic inflammatory processes. Most of the better defined growth factors in man are associated with platelets, polymorphonuclear cells, lymphocytes, monocytes, or connective tissue cells--all cellular elements well represented during the early and later stages of the inflammatory process. As shown in Fig 1, many factors exhibit anabolic or catabolic actions (or both); some seem to play a role in differentiation (EGF, in vivo studies) and several appear to have chemotactic activity that may be important in spatial positioning of cells.

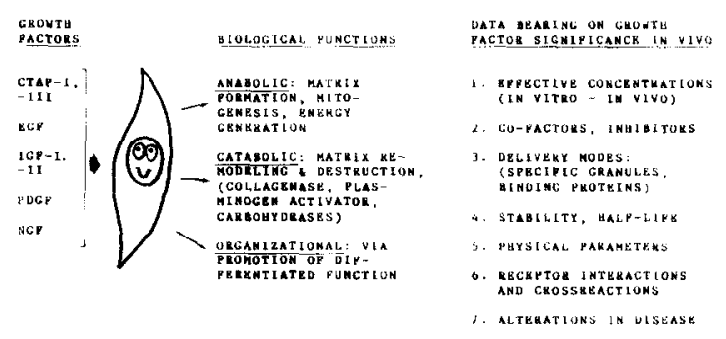

Fig 1. Growth factors in search of employment. This illustration is intended to organize the issues and suggests the magnitude of the problems: clearly each of the three lists could be much longer. 
How does one explain so many factors with many overlapping functions? Are some of in vivo importance and others bioassay artifacts? Is something gained by their acting in concert, in different combinations or sequences? A partial list of types of information that would help to resolve these questions is shown in Fig 1. Sensitive specific immunologic methods permitting sequential measurement of concentrations and locations of multiple factors during the course of well defined pathologic processes would help put these agents into a realistic perspective. The powerful impact of growth factors and the oncogene concept on thinking about the pathogenesis of neoplasia may have an important counterpart in relation to the chronic inflammatory process, which is also characterized by self perpetuation, abnormal cell function, proliferation, and tissue destruction.

\section{COMMENTS}

The preceding sections have alluded to possible roles for various growth factors in normal growth and differentiation, and in the pathogenesis of acute and chronic inflammation, atherosclerosis, wound healing, neoplasia, and certain degenerative diseases. We may expect that the short term future will see the application of quantitative immunoassay and receptor assay techniques to the diagnosis and management of such diseases. Further, it is likely that some growth factors will be available in bulk quantities, either via direct chemical synthesis or by way of recombinant DNA technology; this will provide an opportunity to test such agents as therapeutic modalities on problems such as nonhealing wounds. When the actions of growth factors in health and disease are precisely defined, genetically engineered competitive inhibitors may offer a wide array of useful therapeutic modalities.

\section{REFERENCES}

1. Dempster WI: Space requirements of the seated operator. Geometrical, kinematic, and mechanical aspects of the body with special reference to the limbs, in: Wright Air Development Center Technical Report, 1955, No. 55-159, p 201

2. Vierordt H: Anatomische, physiologische und physikalische Daten und Tabellen zum Gebrauche fur Mediciner. G. Fischer, Jena, 1893
3. Ragsdale CG, Castor CW, Roberts DJ, et al: Connective tissue activating peptide-III. Induction of synthesis and secretion of plasminogen activator by synovial fibroblasts. Arthritis Rheum 27:663-667, 1984

4. Levi-Montalcini R: Effects of mouse tumor transplantation on the nervous system. Ann NY Acad Sci 55:330-344, 1952

5. Cohen S: Isolation of a mouse submaxillary gland protein accelerating incisor eruption and eyelid opening in the new-born animal. J Biol Chem 237:1555-1562, 1962

6. Gregory H, Preston BM: The primary structure of human urogastrone. Int J Pept Protein Res 9:108-118, 1977

7. Doolittle RF, Feng DF, Johnson MS: Computer-based characterization of epidermal growth factor precursor. Nature 307:558-560, 1984

8. Oka Y, Orth DN: Human plasma epidermal growth factor $/ \beta$-urogastrone is associated with blood platelets. J Clin Invest 72:249-259, 1983

9. Cohen S: The epidermal growth factor (EGF). Cancer 51:1787-1791, 1983

10. Hollenberg MD: Epidermal growth factor-urogastrone, a polypeptide acquiring hormonal status. Vitam Horm 37:69-110, 1979

11. Gillespie JM, Marshall RC, Moore GPM, et al: Changes in the proteins of wool following treatment of sheep with epidermal growth factor. J Invest Dermatol 79:197-200, 1982

12. Turley E, Hollenberg MD: Epidermal growth factor stimulates glycosaminoglycan synthesis during palatogenesis. Pharmacologist 22:249, 1980 (abstr)

13. Murdoch GH, Potter E, Nicolaisen AK, et al: Epidermal growth factor rapidly stimulates prolactin gene transcription. Nature 300:192-194, 1982

14. Kumegawa M, Yajima T, Hiramatsu M, et al: Epidermal growth factor stimulates collagen synthesis in liverderived epithelial clone cells. Biochim Biophys Acta 675:305-308, 1981

15. Kumegawa M, Hiramatsu M, Yajima T, et al: Effect of epidermal growth factor on collagen formation in liverderived epithelial clone cells. Endocrinology 110:607-612, 1982

16. Hiramatsu $M, K$ umegawa $M$, Hatakeyama $K$, et al: Effect of epidermal growth factor on collagen synthesis in osteoblastic cells derived from newborn mouse calvaria. Endocrinology 111:1810-1816, 1982

17. Fox CF, Linsley PS, Wrann M: Receptor remodeling and regulation in the action of epidermal growth factor. Fed Proc 41:2988-2995, 1982

18. Davies RL, Grosse VA, Kucherlapati R, et al: Genetic analysis of epidermal growth factor action: Assignment of human epidermal growth factor receptor gene to chromosome 7. Proc Natl Acad Sci USA 77:4188-4192, 1980

19. Downward J, Yarden Y, Mayes E, et al: Close similarity of epidermal growth factor receptor and v-erb-B oncogene protein sequences. Nature 307:521-527, 1984

20. Marquardt H, Hunkapiller MW, Todaro GJ: Rat transforming growth factor type 1: Structure and relation to epidermal growth factor. Science 223:1079-1082, 1984

21. Assoian RK, Frolik CA, Roberts AB, et al: Transforming growth factor- $\beta$ controls receptor levels for epider- 
mal growth factor in NRK fibroblasts. Cell 36:35-41, 1984

22. Schreiber AB, Lax I, Yarden Y, et al: Monoclonal antibodies against receptor for epidermal growth factor induce early and delayed effects of epidermal growth factor. Proc Natl Acad Sci USA 78:7535-7539, 1981

23. Urdea MS, Merryweather JP, Mullnbach GT, et al Chemical synthesis of a gene for human epidermal growth factor urogastrone and its expression in yeast. Proc Natl Acad Sci USA 80:7461-7465, 1983

24. Daniele $S$, Frati L, Fiore C, et al: The effect of the epidermal growth factor (EGF) on the corneal epithelium in humans. Graefes Arch Klin Exp Ophthalmol 210:159-165. 1979

25. Gresik EW, Schenkein I, von der Noen $H$, et al: Hormonal regulation of epidermal growth factor and protease in the submandibular gland of the adult mouse. Endocrinology 109:924-929, 1981

26. Gresik EW, Brennan M, Azmitia E: Age-related changes in EGF and protease in submandibular glands of C57B1/6J mice. Exp Aging Res 8:87-90, 1982

27. Zelkowitz M: Neurofibromatosis fibroblasts: Abnormal growth and binding to epidermal growth factor. Adv Neurol 29:173-188, 1981

28. Heldin C-H, Wasteson A, Westermark B: Partial purification and characterization of platelet factors stimulating the multiplication of normal human glial cells. Exp Cell Res 109:429-437, 1977

29. Castor CW, Ritchie JC, Scott ME, et al: Connective tissue activation. XI. Stimulation of glycosaminoglycan and DNA formation by a platelet factor. Arthritis Rheum 20:859-868, 1977

30. Castor $\mathrm{CW}$, Ritchie JC, Williams $\mathrm{CH}$, et al: Connective tissue activation. XIV. Composition and actions of a human platelet autocoid mediator. Arthritis Rheum 22:260272,1979

31. Castor CW, Miller JW, Walz DA: Structural and biological characteristics of connective tissue activating peptide (CTAP-III), a major human platelet-derived growth factor. Proc Natl Acad Sci USA 80:765-769, 1983

32. Begg GS, Pepper DS, Chesterman CN, et al: Complete convalent structure of human beta-thromboglobulin. Biochemistry 17:1739-1744, 1978

33. Myers SL, Hossler PA, Castor CW: Connective tissue activation XIX: Plasma levels of the CTAP-III platelet antigen in rheumatoid arthritis. J Rheumatol 7:814-819, 1980

34. MacCarter DK, Hossler PA, Castor CW: Connective tissue activation. XXIII: Increased plasma levels of a platelet growth factor (CTAP-III) in patients with rheumatic diseases. Clin Chim Acta 115:125-134, 1981

35. Castor CW, Cobel-Geard SR, Hossler PA, et al: Connective tissue activating peptide-III. XXII. A platelet growth factor in human growth hormone deficient patients. $\mathrm{J}$ Clin Endocrinol Metab 52:128-132, 1981

36. Castor CW, Cobel-Geard SR: Connective tissue activation: Evidence for a second human platelet growth factor Clin Res 28:139A, 1980 (abstr)

37. Cabral AR, Hossler PA, Castor CW: Characteristics of a second platelet growth factor. Arthritis Rhcum 26:S42, 1983 (abstr)

38. Johnsson A, Heldin C-H, Westermark B, et al: Plate- let-derived growth factor: Identification of constituent polypeptide chains. Biochem Biophys Res Commun 104:66-74, 1982

39. Deuel TF, San Huang J, Proffitt RT, et al: Human platelet-derived growth factor. Purification and resolution into two active protein fractions. J Biol Chem 256:88968899,1981

40. Raines EW, Ross R: Platelet-derived growth factor. High yield purification and evidence for multiple forms. J Biol Chem 257:5154-5160, 1982

41. Antoniades HN, Hunkapiller MW: Human plateletderived growth factor (PDGF): Amino-terminal amino acid sequence. Science 220:963-965, 1983

42. Waterfield MD, Scrace GT, Whittle N, et al: Plateletderived growth factor is structurally related to the putative transforming protein $\mathrm{p} 28^{\text {sis }}$ of simian sarcoma virus. Nature 304:35-39, 1983

43. Doolittle RF, Hunkapiller MW, Hood LE, et al: Simian sarcoma virus oncgene, $v$-sis, is derived from the gene (or genes) encoding a platelet-derived growth factor. Science $221: 275-277,1983$

44. Chait A, Ross R, Albert JJ, et al: Platelet-derived growth factor stimulates activity of low density lipoprotein receptors. Proc Natl Acad Sci USA 77:4084-4088, 1980

45. Heldin C-H, Wasteson A, Westermark B: Growth of normal human glial cells in a defined medium containing platelet-derived growth factor. Proc Natl Acad Sci USA 77:6611-6615, 1980

46. Grotendorst GR, Chang T, Seppa HEJ, et al: Plateletderived growth factor is a chemoattractant for vascular smooth muscle cells. J Cell Physiol 113:261-266, 1982

47. Senior RM, Griffin GL, San Huang J, et al: Chemotactic activity of platelet alpha granule proteins for fibroblasts. J Cell Biol 96:382-385, 1983

48. Heldin $\mathbf{C}-\mathbf{H}$, Wasteson A, Westermark B: Interaction of platelet-derived growth factor with its fibroblast receptor. J Biol Chem 257:4216-4221, 1982

49. King GL, Buchwald S: Characterization and partial purification of an endothelial cell growth factor from human platelets. J Clin Invest 73:392-396, 1984

50. Assoian RK, Grotendorst GR, Miller DM, et al: Cellular transformation by coordinated action of three peptide growth factors from human platelets. Nature 309:804 806,1984

51. Rinderknecht E, Humbel RE: Primary structure of human insulin-like growth factor II. FEBS Lett 39:283-286, 1978

52. Rinderknecht E, Humbel RE: The amino acid sequence of human insulin-like growth factor $I$ and its structural homology with proinsulin. J Biol Chem 253:27692776, 1978

53. Zapf J, Schoenle E, Froesch ER: Insulin-like growth factors I and II: Some biological actions and receptor binding characteristics of two purified constituents of nonsuppressible insulin-like activity of human serum. Eur $\mathrm{J}$ Biochem 87:285-296, 1978

54. Reddan Jr, Dziedzic DC: Insulin-like growth factors, IGF-1, IGF-2 and somatomedin $C$ trigger cell proliferation of mammalian epithelial cells cultured in a serum-free mediu. Exp Cell Res 142:293-300, 1982

55. Poggi C, Le Marchand-Brustel Y, Zapf J, et al: 
Effects and binding of insulin-like growth factor $I$ in the isolated soleus muscle of lean and obese mice: Comparison with insulin. Endocrinology 105:723-730, 1979

56. Van Wyk JJ, Svoboda ME, Underwood LE: Evidence from radio-ligand assays that somatomedin- $\mathrm{C}$ and insulinlike growth factor-I are similar to each other or different from other somatomedins. J Clin Endocrinol Metab 50:206208, 1980

57. Klapper DG, Svoboda ME, Van Wyke JJ: Sequence analysis of somatomedin-C: Confirmation of identity with insulin-like growth factor I. Endocrinology 112:2215-2217, 1983

58. Clemmons DR, Underwood LE, Van Wyk JJ: Hormonal control of immunoreactive somatomedin production by cultured human fibroblasts. J Clin Invest 67:10-19, 1981

59. D'Ercole AJ, Stiles AD, Underwood LE: Tissue concentrations of somatomedin $\mathrm{C}$ : Further evidence for multiple sites of synthesis and paracrine or autocrine mechanisms of action. Proc Natl Acad Sci USA 81:935-939, 1984

60. Zapf J, Walter H, Froesch ER: Radioimmunological determination of insulin-like growth factors $I$ and II in normal subjects and in patients with growth disorders and extrapancreatic tumor hypoglycemia. J Clin Invest 68:13211330,1981

61. Van Obberghen-Schilling EE, Rechler MM, Romanus JA, et al: Receptors for insulin-like factor $I$ are defective in fibroblasts cultured from a patient with leprechaunism. J Clin Invest 68:1356-1365, 1981

62. Van Wyk JJ, Russell WE, Li CH: Synthetic somatomedin C: Comparison with natural hormone isolated from human plasma. Proc Natl Acad Sci USA 81:740-742, 1984

63. Salmon WD Jr, Daughaday WH: A hormonally controlled serum factor which stimulates sulfate incorporation by cartilage in vitro. J Lab Clin Med 49:825-836, 1957

64. Rechler MM: Purified human somatomedin A and rat multiplication stimulating activity. Mitogens for cultured fibroblasts that cross-react with the same growth peptide receptors. Eur J Biochem 82:5-12, 1978

65. Rudman CG, Parsons JA: Autoradiograph comparison of growth factors: Influence of growth hormone and somatomedin B on patterns of proline incorporation. Clin Endocrinol 15:319-324, 1981

66. Rechler MM, Zapf J, Nissley SP, et al: Interactions of insulin-like growth factors I and II and multiplicationstimulating activity with receptors and serum carrier proteins. Endocrinology 107:1451-1459, 1980

67. Rechler MM, Nissley SP, King GL, et al: Multiplication stimulating activity (MSA) from the BRL 3A rat liver cell line: Relation to human somatomedins and insulin. $J$ Supramol Struct Cell Biochem 15:253-286, 1981

68. Lachman LB: Human interleukin 1: Purification and properties. Fed Proc 42:121-127, 1983

69. Gery I, Gershon RK, Waksman BH: Potentiation of the T-lymphocyte response to mitogens. I. The responding cell. J Exp Med 136:128-142, 1972

70. Scala G, Allavena P, Djeu JY, et al: Human large granular lymphocytes are potent producers of interleukin-1. Nature 309:56-59, 1984

71. Oppenheim JJ, Gery I: Interleukin-1 is more than an interleukin. Immunology Today 3:113-119, 1982

72. Mizel SB, Dayer J-M, Krane SM, et al: Stimulation of rheumatoid synovial cell collagenase and prostaglandin production by partially purified lymphocyte-activating factor (interleukin 1). Proc Natl Acad Sci USA 78:2474-2477, 1981

73. Postlethwaite AE, Lachman LB, Malnardi CL, et al: Interleukin 1 stimulation of collagenase production by cultured fibroblasts. J Exp Med 157:801-806, 1983

74. Mizel SB, Mizel D: Purification to apparent homogeneity of murine interleukin 1. J Immunol 126:834-837, 1981

75. Gordon MA, Hollenberg MD, Castor CW: Connective tissue activation XXVIII. A connective tissue activating peptide from human urine (CTAP-U). Arthritis Rheum 27:780-788, 1984

76. Myers SL, Castor CW: Connective tissue activation. XV: Stimulation of glycosaminoglycan and DNA synthesis by a polymorphonuclear leucocyte factor. Arthritis Rheum 23:556-563, 1980

77. Angeletti RH, Bradshaw RA: Nerve growth factor from mouse submaxillary gland: Amino acid sequence. Proc Natl Acad Sci USA 68:2417-2420, 1971

78. Harper GP, Thoenen H: Nerve growth factor: Biological significance, measurement, and distribution. J Neurochem 34:5-16, 1980

79. Frazier WA, Angeletti RH, Bradshaw RA: Nerve growth factor and insulin. Science 176:482-488, 1972

80. Vinores SA, Perez-Polo JR: Nerve growth factor and neural oncology. J Neurosci Res 9:81-100, 1983

81. Arnason BGW, Oger J, Pantazis NJ, et al: Secretion of nerve growth factor by cancer cells. J Clin Invest 52:2a, 1974

82. Sherwin SA, Sliski AH, Todaro GJ: Human melanoma cells have both nerve growth factor and nerve growth factor-specific receptors on their cell surfaces. Proc Natl Acad Sci USA 76:1288-1292, 1979

83. Puma P, Buxwer SE, Watson L, et al: Purification of the receptor for nerve growth factor from A875 melanoma cells by affinity chromatography. J Biol Chem 258:3370 3375,1983

84. Hefti F: Is Alzheimer's disease caused by lack of nerve growth factor? Ann Neurol 13:109-110, 1983

85. Gee AP, Boyle MDP, Munger KL, et al: Nerve growth factor: Stimulation of polymorphonuclear leukocyte chemotaxis in vitro. Proc Natl Acad Sci USA 80:7215-7218, 1983

86. Temin HM: Control of multiplication of uninfected rat cells and rat cells converted by murine sarcoma virus. J Cell Physiol 75:107-120, 1970

87. Cooper GM: Cellular transforming genes. Science 218:801-806, 1982

88. Bishop JM: Enemies within: the genesis of retrovirus oncogenes. Cell 23:5-6, 1981

89. Eva A, Robbins KC, Andersen PR, et al: Cellular genes analogous to retroviral onc genes are transcribed in human tumour cells. Nature 295:116-119, 1982

90. Marx JL: Oncogenes amplified in cancer cells. Science 223:40-41, 1984

91. Robbins KC, Devare SG, Reddy EP, et al: In vivo identification of the transforming gene product of Simian sarcoma virus. Science 218:1131-1133, 1982

92. Robbins KC, AAronson SA: Molecular cloning of integrated simian sarcoma virus: Genome organization of 
infectious DNA clones. Proc Natl Acad Sci USA 78:29182922,1981

93. Devare SG, Reddy EP, Law JD, et al: Nucleotide sequence of the simian sarcoma virus genome: Demonstration that its acquired cellular sequences encode the transforming gene product p28 $8^{\text {sis }}$. Proc Natl Acad Sci USA 80:731-735, 1983

94. Favera RD, Gallo RC, Giallongo A, et al: Chromosomal localization of the human homolog (c-sis) of the simian sarcoma virus onc Gene. Science 218:686-688, 1982

95. Josephs SF, Guo C, Ratner L, et al: Human protooncogene nucleotide sequences corresponding to the transforming region of simian sarcoma virus. Science 223:487491,1984

96. Chiu I-M, Reddy EP, Givol D, et al: Nucleotide sequence analysis identifies the human c-sis proto-oncogene as a structural gene for platelet-derived growth factor. Cell 37:123-129, 1984

97. Deuel TF, Huang JS, Huang SS, et al: Expression of a platelet-derived growth factor-like protein in simian sarcoma virus transformed cells. Science 221:1348-1350, 1983

98. Stiles CD: The molecular biology of platelet-derived growth factor. Cell 33:653-655, 1983
99. Lin CR, Chen WS, Kruiger W, et al: Expression cloning of human EGF receptor complementary DNA: Gene amplification and three related messenger RNA products in A431 cells. Science 224:843-848, 1984

100. Heldin C-H, Westermark B: Growth factors: Mechanism of action and relation to oncogenes. Cell 37:9-20, 1984

101. Barker WC, Kayhoff MO: Viral src gene products are related to the catalytic chain of mammalian cAMP. dependent protein kinase. Proc Natl Acad Sci USA 78:2836 2839,1982

102. Marx, JL: Cooperation between oncogenes. Science 222:602-603, 1983

103. Yaron $\mathrm{M}$, Castor CW: Leukocyte-connective tissue cell interaction. I. Stimulation of hyaluronate synthesis by live and dead leukocytes. Arthritis Rheum 12:365-373, 1969

104. Castor CW, Yaron M: Leukocyte-connective tissue cell interaction. II. The specificity, duration, and mechanism of interaction effects. Arthritis Rheum 12:374-386, 1969

105. Castor CW: Regulation of Connective Tissue Metabolism, in McCarty DJ (ed): Arthritis and Allied Conditions. Philadelphia, Lea \& Febiger, 1985, pp 242256 